\title{
Regulation of BDNF and trkB mRNA in Rat Brain by Chronic Electroconvulsive Seizure and Antidepressant Drug Treatments
}

\author{
Masashi Nibuya, Shigeru Morinobu, and Ronald S. Duman \\ Laboratory of Molecular Psychiatry, Departments of Psychiatry and Pharmacology, Yale University School of \\ Medicine, Connecticut Mental Health Center, New Haven, Connecticut
}

The influence of chronic electroconvulsive seizure (ECS) or antidepressant drug treatments on expression of brainderived neurotrophic factor (BDNF) and its receptor, trkB, was examined by in situ hybridization and Northern blot. In frontal cortex, acute ECS increased BDNF mRNA approximately twofold, an effect significantly augmented by a prior course of chronic ECS treatment (10 d). In the hippocampus, the influence of chronic ECS varied between the major subfields. In the dentate gyrus granule cell layer, chronic ECS decreased the acute induction of BDNF and trkB mRNA by $\sim 50 \%$, but prolonged their expression: levels remained elevated two- to threefold $18 \mathrm{hr}$ later after the last chronic ECS treatment, but returned to control $18 \mathrm{hr}$ after acute ECS. In CA3 and CA1 pyramidal cell layers, chronic ECS significantly elevated the acute induction of BDNF, and tended to prolong the expression of BDNF and trkB mRNA. A similar effect was observed in layer 2 of the piriform cortex, where chronic ECS significantly increased the acute induction and prolonged the expression of BDNF and trkB mRNA. Chronic (21 d), but not acute (1 d), administration of several different antldepressant drugs, Including tranylcypromine, sertraline, desipramine, or mianserin, significantly increased BDNF mRNA and all but mianserin increased trkB mRNA in hippocampus. In contrast, chronic administration of nonantidepressant psychotropic drugs, including morphine, cocaine, or haloperidol, did not increase levels of BDNF mRNA. Furthermore, chronic administration of ECS or antidepressant drugs completely blocked the downregulation of BDNF mRNA in the hippocampus in response to restraint stress. The enhanced induction and prolonged expression of BDNF in response to chronic ECS and antidepressant drug treatments could promote neuronal survival, and protect neurons from the damaging effects of stress.

[Key words: desipramine, sertraline, tranylcypromine, mianserin, stress, hippocampus, frontal cortex]

Effective treatments for depression have been available for over 35 years, but the neurochemical effects that underlie the therapeutic action of these treatments remain largely unknown. Many antidepressant drugs acutely increase levels of monoamines, but

Received Apr. 14, 1995; revised July 12, 1995; accepted July 20, 1995.

This work was supported by USPHS Grants MH45481, MH51399, and 2 PO1 MH25642, and by a Veterans Administration National Center grant for PTSD, VA Hospital in West Haven, CT.

Correspondence should be addressed to Dr. Konald S. Duman, Connecticut Mental Health Center, 34 Park Street, New Haven, CT 06508.

Copyright (C) 1995 Society for Neuroscience 0270-6474/95/157539-09\$05.00/0 the requirement for repeated, chronic administration has lead to the hypothesis that long-term adaptations are necessary for the therapeutic actions of these treatments (see Heninger and Charney, 1987; Sulser, 1989; Hudson et al., 1993; Duman et al., 1994). Similarly, the mechanism of action of electroconvulsive seizures (ECS), probably the most effective treatment for depression, including cases that are not responsive to antidepressant drug regimens, has not been identified.

Recent work has raised the novel possibility that among the many long-term targets of antidepressant treatments may be regulation of neurotrophins. Neurotrophins promote the growth and development of immature neurons and enhance the survival and function of adult neurons (see Lindsay et al., 1994; Lindvall et al., 1994). A role for brain-derived neurotrophin factor (BDNF), the most abundant neurotrophin in the brain, in the action of antidepressant treatments is supported by scveral lincs of evidence. First, electrical or chemical-induced seizures increase the expression of BDNF and its receptor, trkB, in the hrain (Frnfors et al., 1991; Isackson et al., 1991). Second, local infusion of BDNF into the midbrain has antidepressant effects in two behavioral models of depression, the forced-swim and learnedhelplessness paradigms (Siuciak et al., 1994a). This suggests that increased expression of endogenous BDNF may have antidepressant effects. Third, stress decreases the expression of BDNF in the hippocampus and other limbic brain regions (Smith et al., 1995), an effect that could contribute to the recently demonstrated atrophy of stress-vulnerable neurons in the hippocampus (Sapolsky et al., 1985, 1990; Uno et al., 1989; Wooley et al., 1990; Watanabe et al., 1992; Stein-Behrens et al., 1994). Stress-induced atrophy, and, in extreme cases, cell death, may contribute to the loss of hippocampal control of the hypothalamic-pituitary-adrenal axis (HPA) and hypercortisolism often exhibited in depression (see Herman et al., 1989; Jacobson and Sapolsky, 1991; Young ct al., 1991).

The present study tests the hypothesis that antidepressant treatments regulate the expression of BDNF and trkB mRNA, using several lines of investigation. First, the influence of acute and chronic ECS treatments on expression of BDNF and trkB mRNA was determined. Second, the influence of chronic antidepressant drug treatments on expression of BDNF and trkB was determined. The drugs tested included tranylcypromine, a monoamine oxidase inhibitor; desipramine, a norepinephrine-selective reuptake inhibitor; sertraline, a serotonin-selective reuptake inhibitor; and mianserin, an atypical antidepressant. The pharmacological specificity of the antidepressant drugs was examined by comparison with several nonantidepressant psychotropic drugs, including morphine, cocaine, and haloperidol. Third, the 
possibility that antidepressant treatments may block the downregulation of BDNF in response to stress was examined. The brain regions chosen for study were the frontal cortex and hippocampus, which have been implicated in the pathophysiology and treatment of depression and stress (see Heninger and Charney, 1987; Baxter et al., 1989; Herman et al., 1989; Jacobson and Sapolsky, 1991; Young et al., 1991; Drevets et al., 1992; Duman et al., 1994); for comparison, expression of BDNF and trkB mRNA in the piriform cortex was examined. The results demonstrate that chronic ECS and antidepressant drugs enhance the induction and prolong the expression of BDNF and trkB mRNA, and block the downregulation of BDNF mRNA in response to stress.

\section{Materials and Methods}

Animals and treatment paradigms. Male Sprague-Dawley rats (150$200 \mathrm{gm}$ ) (CAMM. Wayne, NJ) were group housed and maintained on a $12 \mathrm{hr}$ light-dark cycle with food and water freely available. All treatments were according to standard protocols as previously described (see Nestler et al., 1989; Hayward et al., 1990; Hosoda and Duman, 1993; Morinobu et al.. 1995). Rats were administered (once daily) ECS via earclip electrodes $(50 \mathrm{~mA}, 0.3 \mathrm{sec})$ or received sham treatment (handled identically as those that received ECS, but without electrical stimulation). The influence of acute and chronic ECS on levels of BDNF and trkB mRNA were determined by in situ and Northern blot analysis using the following treatment paradigms: \#1 (four groups) sham: sham treatment for $10 \mathrm{~d}(n=8)$; chronic $+18 \mathrm{hr}$ : ECS for $10 \mathrm{~d}$ and sacrificed $18 \mathrm{hr}$ after the last treatment $(n=8)$; acute $+2 \mathrm{hr}$ : sham treatment once daily for $9 \mathrm{~d}$, acute ECS on day 10 , and sacrificed $2 \mathrm{hr}$ later $(n=$ 8): or chronic $+2 \mathrm{hr}$ : ECS daily for $10 \mathrm{~d}$ and sacrificed $2 \mathrm{hr}$ after the last treatment $(n=6)$. \#2 (two groups) sham: I sham treatment $(n=$ 3); or acute + $18 \mathrm{hr}$ : a single ECS and sacrificed $18 \mathrm{hr}$ later $(n=3)$. For Northern blot analysis, the number of rats per group was as follows: \#1 sham $(n=16)$; chronic +18 hr $(n=12)$; acute +2 hr $(n=7)$; or chronic $+2 \mathrm{hr}(n=7)$ : Northern blot analysis of both BDNF and trkB mRNA could not determined for a few of these samples due to loss or insufficient recovery of RNA; \#2 sham $(n=4)$ or acute +18 hr $(n=4)$.

For drug treatments, groups of rats were administered tranylcypromine $(7.5 \mathrm{mg} / \mathrm{kg}$ for $7 \mathrm{~d}$ then $10 \mathrm{mg} / \mathrm{kg}$ for $14 \mathrm{~d})$, imipramine $(15 \mathrm{mg} / \mathrm{kg})$, desipramine $(15 \mathrm{mg} / \mathrm{kg})$, sertraline $(10 \mathrm{mg} / \mathrm{kg})$, mianserin $(10 \mathrm{mg} / \mathrm{kg})$, haloperidol ( $2 \mathrm{mg} / \mathrm{kg}$ ), cocaine (15 $\mathrm{mg} / \mathrm{kg})$, or vehicle $(0.9 \%$ saline) once daily for $21 \mathrm{~d}$ via intraperitoneal injection and sacrificed $3 \mathrm{~h}$ after the last treatment. For morphine treatment, rats were administered morphine pellets $(75 \mathrm{mg}$ pellets, s.c.) once daily for $5 \mathrm{~d}$ or received the same sham treatment (sham surgery without morphine pellet). Chronic drug treatment groups were as follows: \#1, antidepressant drugs (five groups): vehicle $(n=16)$; sertraline $(n=9)$; desipramine $(n=10)$; tranylcypromine $(n=6)$; or mianserin $(n=6)$ : Northern blot analysis of both BDNF and trkB mRNA could not be conducted for a few of these samples due to loss or insufficient recovery of RNA; \#2, nonantidepressant drugs (three groups: vehicle $(n=6)$; cocaine $(n=6)$; or haloperidol ( $n=6$ ); and $\# 3$, nonantidepressant drugs (two groups) sham $(n=6)$ or morphine $(n=6)$. Doses for acute $(3 \mathrm{hr})$ antidepressant drug treatments were exactly as described above (five groups): vehicle ( $n=$ $8)$, tranylcypromine $(n=8)$, sertraline $(n=4)$, desipramine $(n=4)$, or mianserin $(n=4)$.

For stress experiments, rats were subjected to restraint stress (45 min) $18 \mathrm{hr}$ after the last sham or antidepressant treatments, and then sacrificed immediately. The treatment groups were as follows: experiment 1: vehicle/sham $(n=8)$, vehicle/stress $(n=7)$, desipramine/stress $(n=4)$, tranylcypromine/stress $(n=4)$, or sertraline/stress $(n=4)$, experiment \#2: vehicle/sham $(n=3)$, vehicle/stress $(n=3)$, or ECS/stress $(n=$ 3).

Brains were removed and immediately frozen for in situ hybridization, or sections of frontal cortex or hippocampus were dissected for RNA extraction and Northern blot analysis, as described below. All animal use procedures were in strict accordance with the National Institutes of Health Guide for the Care and Use of Laboratory Animals and were approved by the Yale Animal Care Committee. The drugs used for these studies were obtained from the following sources: tranylcypromine, imipramine, desipramine, and haloperidol were purchased from Sigma (St. Louis, MO), mianserin was purchased from Research Biochemicals Incorporated (Natick, MA), sertraline was a generous gift of Pfizer Central Research (Groton, CT), and morphine and cocaine from the National Institute on Drug Abuse (Baltimore, MD).

In situ hybridization analysis. Analysis of BDNF mRNA by in situ hybridization was conducted as previously described by this laboratory (see Hayward et al., 1990). Briefly, coronal sections of frozen brain (16 $\mu \mathrm{m})$ were cut on a cryostat and stored at $-70^{\circ} \mathrm{C}$. Tissue sections were thaw mounted on RNase-free Probon slides (Fisher), fixed, and dried. Rat BDNF and mouse trkB cDNA clones were provided by Regeneron (Tarrytown, NY) and the National Cancer Institute (Frederick, MD). The BDNF cDNA, subcloned into pBluescript SK- (Stratagene, La Jolla, CA), was linearized with ESP1 and uniformly radiolabeled riboprobes corresponding to the antisense strand (bp 507-833) were generated with T7 RNA polymerase and ${ }^{35} \mathrm{~S}-\mathrm{CTP}$ (Dupont NEN, Boston, MA) as previously described (Hosoda et al., 1993). The trkB cDNA, in pBluescript SK-, was linearized with HINDIII and radiolabeled riboprobes corresponding to the antisense strand (bp 1181-1663) were generated with T7 RNA polymerase. The ${ }^{35}$ S-labeled BDNF or trkB riboprobes were hybridized with the brain sections ( $10^{\circ} \mathrm{CPM}$ per section) for $18 \mathrm{hr}$ at $55^{\circ} \mathrm{C}$ in hybridization buffer $(50 \%$ formamide, $0.6 \mathrm{M} \mathrm{NaCl}, 10$ mM Tris, $1 \times$ Denhardt's solution, 2 mm EDTA, 10 mм DTT, $10 \%$ dextran sulfate, $50 \mu \mathrm{g} / \mathrm{ml}$ salmon sperm DNA, and $250 \mathrm{mg} / \mathrm{ml}$ tRNA). The sections were washed in $2 \times$ SSC (SSC: $0.15 \mathrm{M} \mathrm{NaCl}, 0.015 \mathrm{M}$ sodium citrate at $\mathrm{pH} 7.0$ ) at $25^{\circ} \mathrm{C}$, and then treated with $20 \mu \mathrm{g} / \mathrm{ml}$ RNase A for $45 \mathrm{~min}$ in $0.5 \mathrm{M} \mathrm{NaCl}, 10 \mathrm{~mm}$ Tris, and $1 \mathrm{~mm}$ EDTA. The sections were then washed twice in $0.2 \times \mathrm{SSC}$ at $55^{\circ} \mathrm{C}, 30 \mathrm{~min}$ per wash. The sections were dried, exposed to Hyperfilm (Amersham), and subsequently counterstained with cresyl violet to allow alignment with the autoradiogram. The specificity of the hybridization was confirmed by demonstrating that ${ }^{35} \mathrm{~S}$-labeled sense BDNF and trkB riboprobes did not yield any significant hybridization (not shown).

Northern blot analysis. Total RNA was isolated from sections of frontal cortex and hippocampus by the guanidine isothiocyanate/cesium chloride centrifugation method, as previously described (Hosoda et al., 1993; Morinobu et al., 1995). Levels of BDNF and trkB mRNA were determined by Northern blot analysis using " ${ }^{32}$-labeled riboprobes as previously described (Hosoda et al., 1993). Briefly, $20 \mu \mathrm{g}$ of total RNA was electrophoresed on a $1 \%$ agarose gel and the RNA was transferred to nitrocellulose filters. The resulting filters were then incubated with the ${ }^{32} \mathrm{P}$-labeled $\mathrm{BDNF}$ and trkB riboprobes for $18 \mathrm{hr}$ at $65^{\circ} \mathrm{C}$ and washed in $2 \times \mathrm{SSC}, 0.1 \%$ sodium dodecyl sulfate (SDS) at $65^{\circ} \mathrm{C}$ for $30 \mathrm{~min}$, and then twice in $0.2 \times \mathrm{SSC}, 0.1 \%$ SDS at $65^{\circ} \mathrm{C}$ for $60 \mathrm{~min}$. Levels of total RNA for each lane were determined by reprobing the nitrocellulose filters with a ${ }^{32} \mathrm{P}$-labeled cyclophilin cDNA probe, that was radiolabeled using a random prime kit (Stratagene, La Jolla, CA) as previously described (Morinobu et al., 1995). The radiolabeled mRNA bands were visualized by autoradiography and quantitated with a GSXL laser densitometer. The level of BDNF or trkB mRNA was divided by cyclophilin mRNA to account for differences in the amount of RNA per lane. The results are expressed as percent of sham.

Data analysis. Levels of BDNF and trkB mRNA were determined by outlining the band on Northern blots or the regions of interest on in situ hybridization sections and then quantified on a MacIntosh-based NIH IMAGE analysis program, version 1.52; an equivalent area on the Northern blot or brain section was outlined for each sample. ${ }^{1+} \mathrm{C}$ step standards were used to verify the linearity of densitometry. For in situ hybridization sections, the following regions were analyzed: frontal cortex superficial layer, dentate gyrus granule cell layer. $\mathrm{CA}_{3}$ and $\mathrm{CA} I$ pyramidal cell layers, and piriform cortex pyramidal cell layer. For each animal, both sides of three individual brain sections were analyzed, for a total of six determinations, and the mean was determined. The results were then subjected to statistical analysis. Experiments containing groups of three or more (see treatment paradigms above) were subjected to analysis of variance, with a significance level of $p<0.05$, and Fisher's post hoc test. Experiments containing two groups were subjected to Student's $t$ test, with significance determined at the $p<0.05$ level.

\section{Results}

\section{Chronic ECS increases seizure-induction of BDNF and trkB $m R N A$ in the frontal cortex}

The influence of ECS on the expression of BDNF and trkB was examined by in situ hybridization and Northern blot analysis. Two hours after acute ECS levels of BDNF mRNA were sig- 

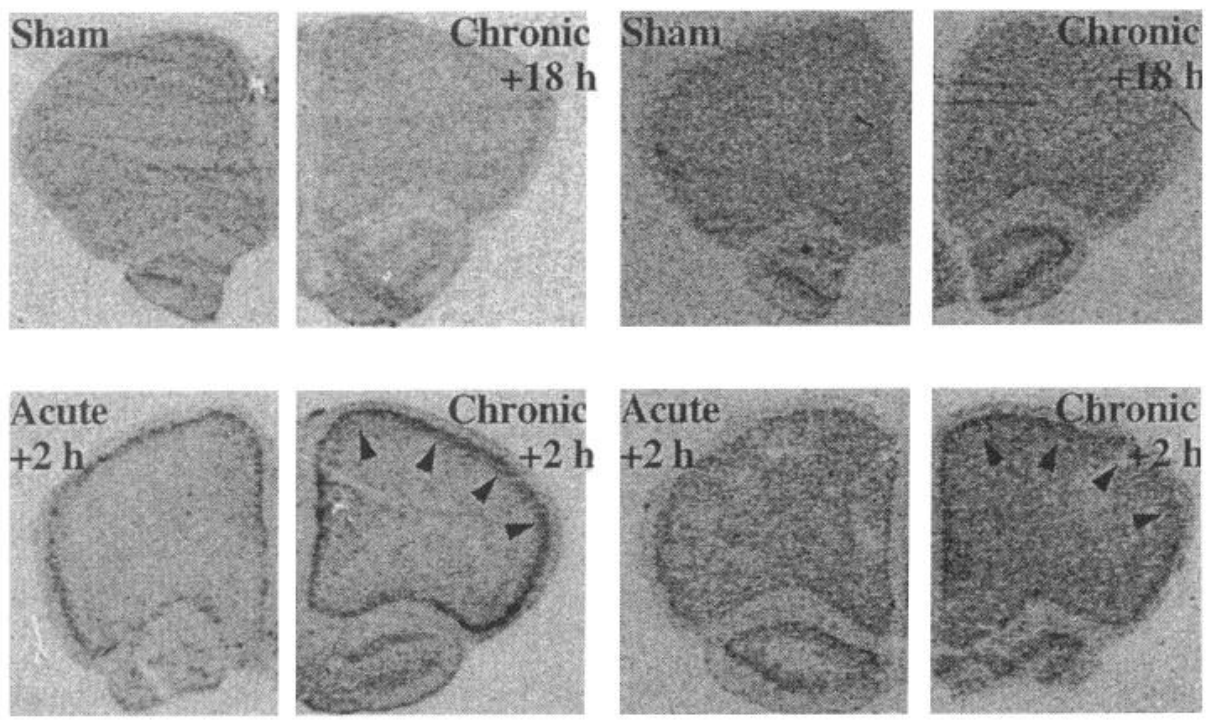

BDNF
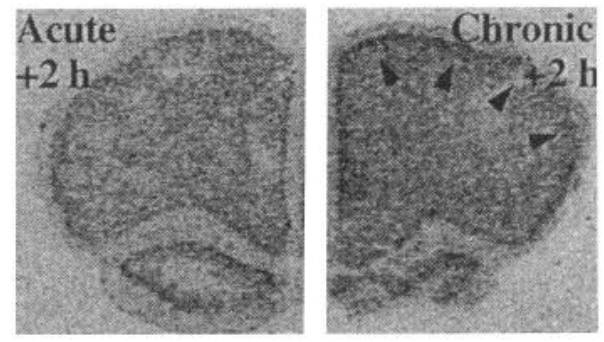

trkB
Figure 1. Regulation of BDNF and trkB mRNA in frontal cortex by acute and chronic ECS. Levels of BDNF and trkB mRNA were determined $2 \mathrm{hr}$ after sham (sham), $2 \mathrm{hr}$ after a single ECS (Acute $+2 \mathrm{~h}), 2 \mathrm{hr}$ after chronic (10 d) ECS (chronic $+2 h$ ), or $18 \mathrm{hr}$ after chronic ECS (chronic $+18 \mathrm{~h}$ ). Radiolabeled BDNF and trkB riboprobes were used for in situ hybridization analysis of BDNF and trkB mRNA as described in Materials and Methods. Representative autoradiograms of BDNF and trkB mRNA are shown for each of the four conditions. Arrowheads indicate the induction of BDNF and trkB mRNA in superficial layers of frontal cortex. nificantly increased in frontal cortex (Figs. 1-3). Preliminary studies demonstrated that ECS-induction of BDNF was maximum at the $2 \mathrm{hr}$ time point, which was used for all acute treatments thereafter. BDNF remained elevated for $\sim 4$ to $6 \mathrm{hr}$ after acute ECS (not shown) and returned to basal levels $18 \mathrm{hr}$ after treatment (Fig. 2). Levels of trkB mRNA tended to be increased

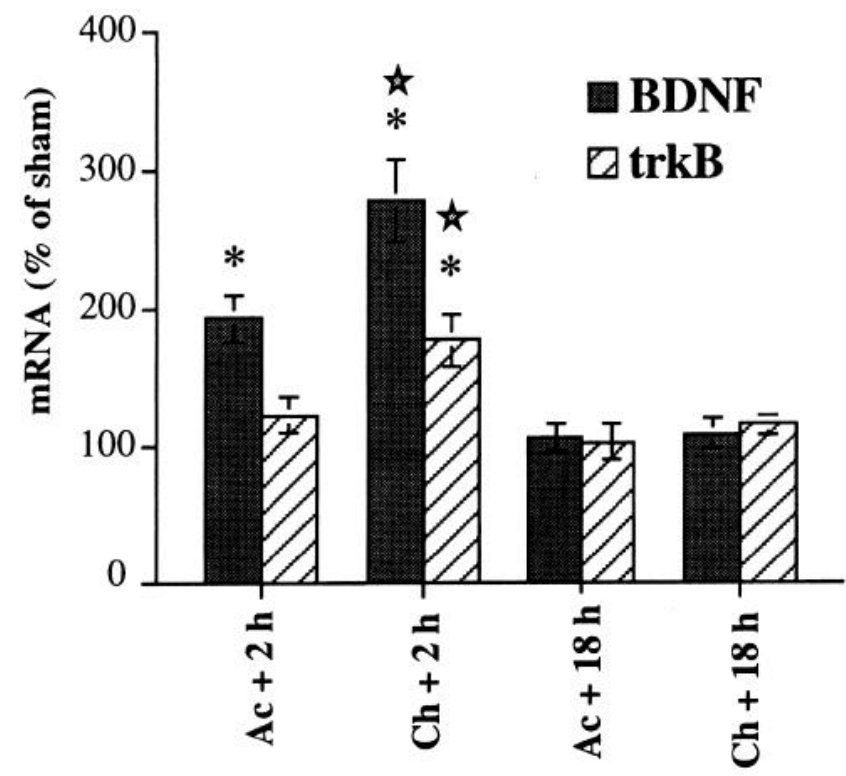

Figure 2. Chronic ECS increases the induction of BDNF and trkB mRNA in frontal cortex. The influence of acute and chronic ECS on the level of BDNF and trkB mRNA was determined as described in Figure 1. In addition to the four groups described in Figure 1, the level of BDNF mRNA $18 \mathrm{hr}$ after acute ECS (acute $+18 \mathrm{~h}$ ) was also determined. Note that acute $(A c)$ and chronic $(C h)$ are abbreviated as indicated. Levels of BDNF and trkB mRNA were determined by quantitative densitometry of the superficial layer of frontal cortex, as indicated by arrowheads in Figure 1. Results are expressed as percent of sham and are the mean \pm SEM. Analysis of variance comparing BDNF or trkB mRNA levels in sham or ECS groups revealed a significant difference: BDNF mRNA $[F(3,26)=18.99, p<0.0001]$; trkB mRNA $[F(3,26)=7.19, p<0.01]$; the indicated groups were found to be significantly different from the vehicle-treated group (Fisher's test): *compared to sham; iscompared to acute $+2 \mathrm{hr}$.
$2 \mathrm{hr}$ after acute ECS, but this effect was not significant (Figs. 1-3). In situ hybridization analysis demonstrated that ECS induction of BDNF mRNA occurred primarily in superficial layers of frontal and cingulate cortex (Fig. 1). Northern blot analysis confirmed the acute ECS regulation of BDNF (Fig. 3); two major mRNA bands, $\sim 1.8$ and $4.4 \mathrm{~kb}$, were observed, with the smaller band being significantly regulated by acute ECS. These mRNA species result from expression of different exons of the BDNF gene and both encode full length BDNF (Timmusk et al., 1993). Northern blot analysis reveals two major trkB mRNA bands, of approximately 7.5 and $9.0 \mathrm{~kb}$, as well as several minor bands (Fig. 3); the $9.0 \mathrm{~kb}$ trkB band encodes full length trkB, while the $7.5 \mathrm{~kb}$ band encodes a truncated form of the receptor that lacks the intracellular tyrosine kinase domain (Middlemas et al., 1991).

The influence of chronic ECS (once daily for $10 \mathrm{~d}$ ) on levels of BDNF and trkB mRNA was examined $2 \mathrm{hr}$ or $18 \mathrm{hr}$ after last treatment, to determine if either the induction or basal expression of BDNF and trkB mRNA are altered. Chronic ECS significantly increased the induction of BDNF mRNA in the superficial layers of frontal and cingulate cortex $2 \mathrm{hr}$ after the last treatment (Figs. $1,2)$. This was confirmed by Northern blot analysis of sections of frontal and cingulate cortex, which demonstrated that both major BDNF mRNA bands were increased by chronic ECS relative to acute treatment (Fig. 3). In situ analysis revealed that levels of trkB mRNA in the frontal and cingulate cortex were also significantly elevated $2 \mathrm{hr}$ after the last chronic ECS treatment (Figs. 1, 2). Northern blot analysis confirmed this effect, and demonstrated that chronic ECS treatment increased both the 9.0 and $7.5 \mathrm{~kb}$ trkB mRNA bands (Fig. 3). Levels of BDNF and trkB mRNA were not significantly different from sham $18 \mathrm{hr}$ after the last chronic treatment (Fig. 3).

\section{Chronic ECS increases basal and seizure-induction of BDNF and trkB mRNA in the hippocampus and piriform cortex}

Acute induction of BDNF and trkB mRNA 2 hr after ECS differed in the subfields of the hippocampus. In the dentate gyrus, granule cell layer levels of BDNF and trkB mRNA were elevated $\sim 30$ - and fivefold, respectively (Figs. 4, 5). Levels of $\mathrm{BDNF}$ and trkB mRNA in the dentate gyrus granule cell layer 


\section{BDNF}

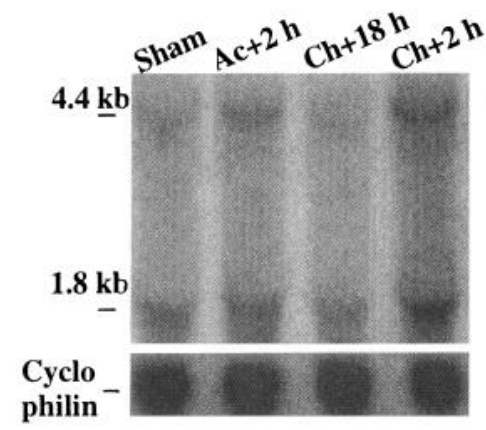

\section{trkB}
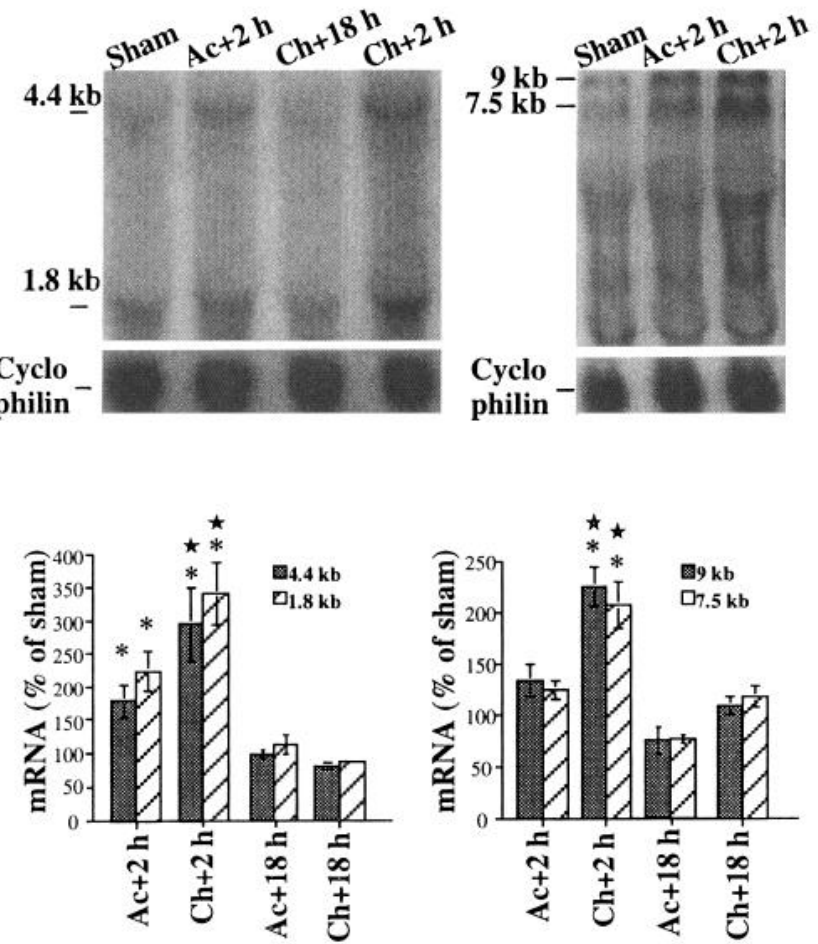

Figure 3. Northern blot analysis of BDNF and trkB mRNA in frontal cortex: regulation by acute and chronic ECS. The influence of acute and chronic ECS on the level of BDNF and trkB mRNA was determined by Northern blot as described in Materials and Methods. The location of the major BDNF and trkB mRNA bands are indicated. The level of mRNA in each band was quantified by densitometry and standardized for the amount of mRNA in each lane, which was determined by reprobing the filters with radiolabeled cyclophilin. Results are expressed as percent of sham and are the mean \pm SEM. Analysis of variance comparing BDNF or trkB mRNA levels revealed the following differences: BDNF $4.4 \mathrm{~kb}$ band $[F(3,38)=22.38, p<0.0001]$; $\mathrm{BDNF}$ $1.8 \mathrm{~kb}$ band $[F(3,38)=39.7, p<0.0001]$; trkB $9.0 \mathrm{~kb}$ band $[F(3,36)$ $=23.57, p<0.0001]$; and trkB $7.5 \mathrm{~kb}$ band $[F(3,36)=21.40, p<$ $0.0001]$. The indicated groups were found to be significantly different from the vehicle-treated group (Fisher's test): *compared to sham; st compared to acute $+2 \mathrm{hr}$

were significantly increased $2 \mathrm{hr}$ after ECS and returned to basal levels $18 \mathrm{hr}$ later (Fig. 5). In the CA3 pyramidal cell layer, acute ECS increased levels of both BDNF and trkB mRNA by $\sim 75 \%$ (Figs. 4, 5); $18 \mathrm{hr}$ later, levels of BDNF mRNA were significantly decreased relative to sham (Fig. 5). In the CAl pyramidal cell layer there was a tendency for BDNF mRNA to be increased by acute ECS, although this effect was not significant (Fig. 5). The induction of BDNF and trkB mRNA was confirmed by Northern blot analysis of mRNA extracted from whole hippocampus (Fig. 6); this probably represents mRNA predominately from the dentate gyrus granule cell layer, given the higher basal levels and greater ECS induction of BDNF and trkB mRNA in this cell layer of the hippocampus (see Figs. 4, 5).

The influence of chronic ECS differed qualitatively between the subfields of the hippocampus. In the dentate gyrus granule cell layer, the induction of BDNF and trkB mRNA in response to acute ECS $(2 \mathrm{hr})$ was significantly increased relative to sham, but was reduced when compared to acute ECS alone (Figs. 4, 5). In addition, basal levels of BDNF and trkB mRNA remained significantly increased $18 \mathrm{hr}$ after the last chronic treatment
(Figs. 4, 5). A similar pattern of regulation was observed by Northern blot analysis of BDNF and trkB mRNA extracted from whole hippocampus, although levels of trkB mRNA were not significantly increased $18 \mathrm{hr}$ after the last treatment (Fig. 6). In CA3 and CA1 pyramidal cell layers acute ECS induction $(2 \mathrm{hr})$ of BDNF was significantly increased relative to acute ECS alone (Figs. 4, 5); acute ECS significantly increased levels of trkB mRNA relative to sham, but not relative to acute ECS alone (Figs. 4, 5).

The influence of ECS on levels of BDNF and trkB mRNA in piriform cortex were determined by in situ hybridization analysis. Acute ECS increased levels of BDNF and trkB mRNA $\sim$ five- and twofold, respectively, in layer 2 of piriform cortex (Figs. 4, 5). This was the only brain region where levels of BDNF mRNA remained elevated $18 \mathrm{hr}$ after acute ECS treatment (Fig. 5). Chronic ECS treatment increased the acute induction of BDNF mRNA, but not trkB mRNA, in piriform cortex. Moreover, basal levels of both BDNF and trkB mRNA remained significantly increased $18 \mathrm{hr}$ after the last chronic treatment (Figs. 4, 5).

\section{Chronic antidepressant drug treatments increase the expression of BDNF and trkB $\mathrm{mRNA}$}

The influence of chronic (21 d) antidepressant drug treatments on levels of BDNF and trkB mRNA was examined by Northern blot analysis. In frontal cortex, chronic administration of tranylcypromine increased levels of BDNF, but not trkB, mRNA by $\sim 100 \%$ (Table 1): this was the only antidepressant drug tested that significantly increased expression of BDNF in this brain region. In the hippocampus, all of the antidepressants tested significantly increased levels of BDNF mRNA, and all but mianserin significantly increased levels of trkB mRNA (Fig. 7, Table 2). Chronic administration of tranylcypromine increased levels of BDNF and trkB mRNA by $\sim 70$ and $40 \%$, respectively. Chronic mianserin treatment increased levels of BDNF mRNA by $\sim 40 \%$. Chronic sertraline and desipramine treatments significantly increased levels of BDNF and trkB mRNA by $\sim 20$ to $40 \%$ (Fig. 7, Table 2). In contrast, acute administration of these antidepressant drugs did not significantly influence levels of BDNF mRNA in the hippocampus (Table 2).

Chronic administration of nonantidepressant psychotropic drugs does not influence levels of BDNF and trkB $m R N A$

To determine the pharmacological specificity of the antidepressant drugs, the influence of several nonantidepressant psychotropic drugs on expression of BDNF and trkB mRNA was determined; this included morphine, an opiate agonist; haloperidol, an antipsychotic- $\mathrm{D}_{2}$-dopamine receptor antagonist; and cocaine, a psychostimulant that blocks the reuptake of dopamine, as well as serotonin and norepinephrine. Chronic administration of morphine (5 d) did not significantly influence levels of BDNF or trkB mRNA in the frontal cortex or hippocampus (Tables 1 and 2). Likewise, chronic administration of cocaine (21 d) or haloperidol (21 d) did not increase the expression of BDNF or trkB mRNA in either the frontal cortex or hippocampus (Tables 1 and 2). In fact, chronic haloperidol treatment decreased levels of the $1.8 \mathrm{~kb}$ BDNF mRNA band in the hippocampus (Table 2).

\section{Chronic antidepressant treatments block stress-induced downregulation of BDNF $m R N A$}

Stress is reported to decrease the expression of BDNF mRNA in the hippocampus (Smith et al., 1995). Studies were undertak- 

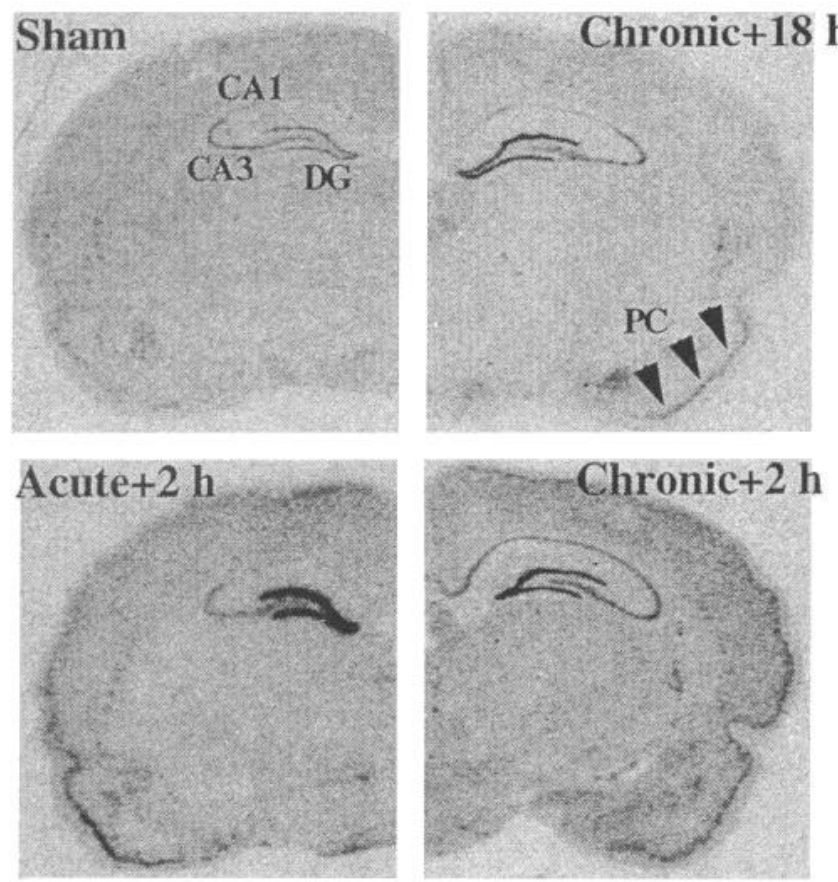
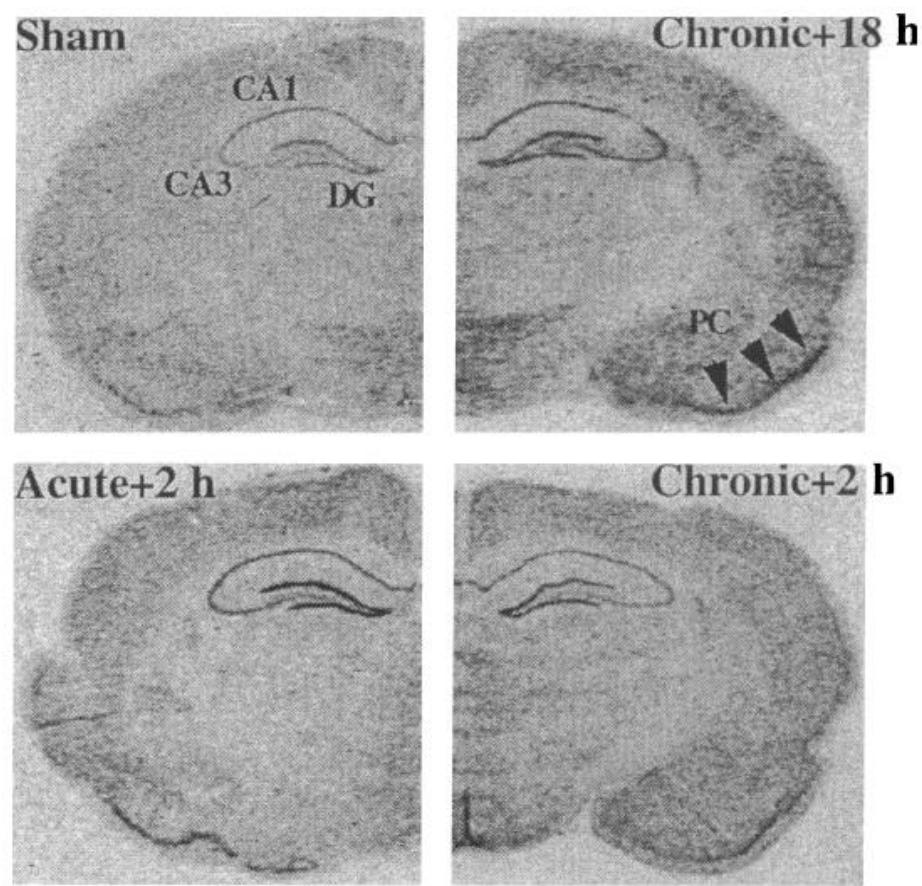

BDNF

\section{trkB}

Figure 4. Regulation of BDNF and trkB mRNA in hippocampus and piriform cortex by acute and chronic ECS. The influence of acute and chronic ECS treatments on levels of BDNF and trkB mRNA were determined by in situ hybridization as described in Materials and Methods. Representative autoradiograms for each of the four treatment conditions are shown. The CA1 pyramidal cell layer (CAl), CA3 pyramidal cell layer $(C A 3)$, dentate gyrus granule cell layer $(D G)$, and layer 2 of piriform cortex $(P C)$ are indicated.

\section{Dentate gyrus}

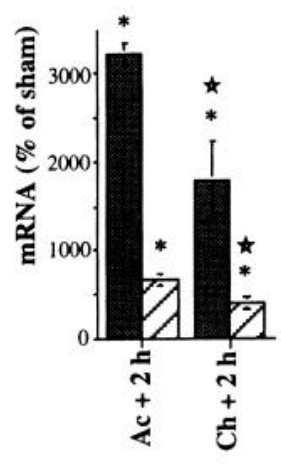

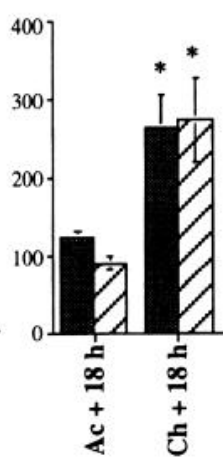

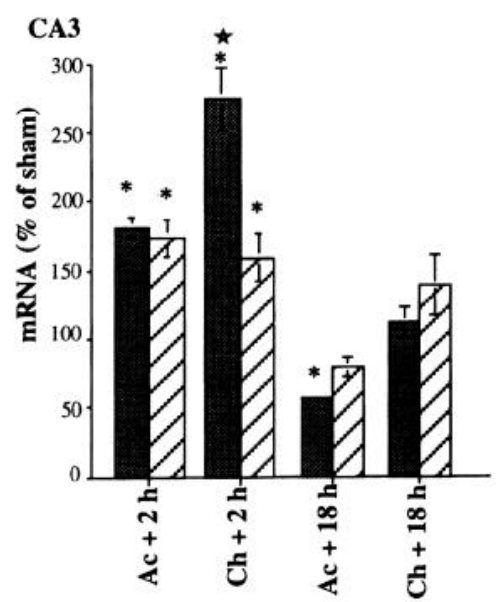

\section{Piriform cortex}
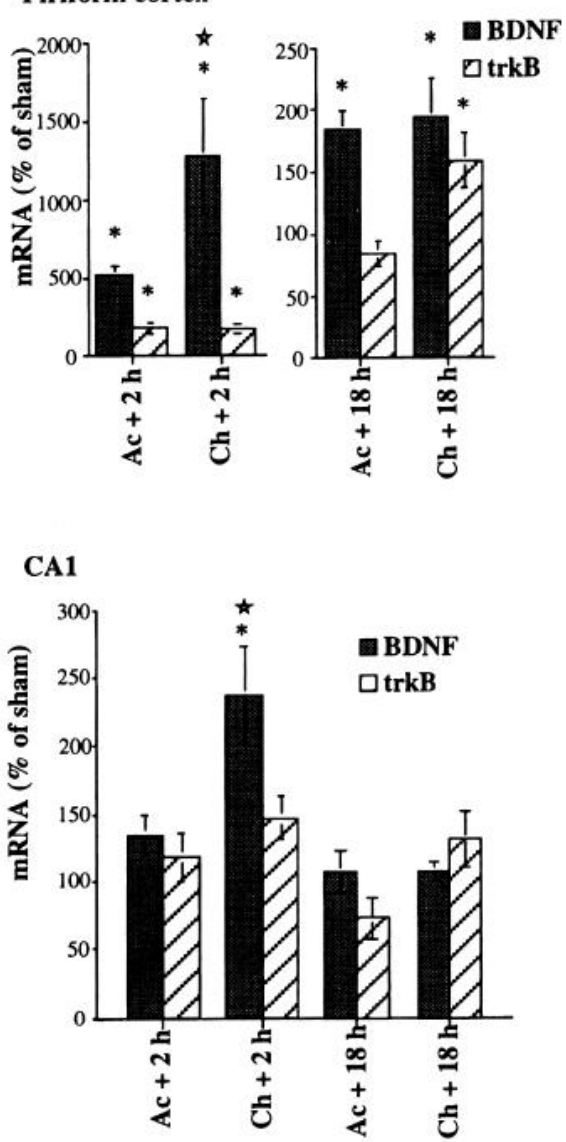

Figure 5. Regulation of BDNF and trkB mRNA levels in subfields of hippocampus and piriform cortex. Levels of BDNF and trkB mRNA in dentate gyrus granule cell layer, layer 2 of piriform cortex, and CA3 and CAl pyramidal cell layers were determined by quantitative densitometry of in situ hybridization autoradiograms like those presented in Figure 4. The results are presented as percent of sham $(100 \%)$ and are the mean \pm SEM. Note that the scales for the $y$-axis for each subfield are different. In addition, the scales for $2 \mathrm{hr}$ and $18 \mathrm{hr}$ in dentate gyrus and piriform cortex are different because of the dramatic induction of BDNF in these areas at the $2 \mathrm{hr}$ time point. Analysis of variance comparing BDNF or trkB mRNA levels in each region revealed the following differences: dentate gyrus granule cell layer, BDNF $\operatorname{mRNA}[F(3,26)=60.73, p<0.0001]$ and trkB mRNA $[F(3,26)=52.94, p$ $<0.0001$ ]; piriform cortex, BDNF $\operatorname{mRNA}[F(3,26)=7.26, p<0.01]$ and trkB mRNA $[F(3,26)=3.89, p<$ 0.05 ]; CA3 pyramidal cell layer BDNF mRNA $[F(3,26)=18.08, p<0.0001]$ and trkB mRNA $[F(3,26)=4.32, p<$ 0.05 ]; and CA1 pyramidal cell layer BDNF mRNA $[F(3,26)=7.49, p<$ $0.001]$. The indicated groups were found to be significantly different from the vehicle-treated group (Fisher's test): *compared to sham; iscompared to acute $+2 \mathrm{hr}$. 


\begin{tabular}{|c|c|c|c|c|}
\hline \multirow[b]{2}{*}{ Treatment } & \multicolumn{2}{|c|}{ BDNF mRNA } & \multicolumn{2}{|c|}{ trkB mRNA } \\
\hline & $4.4 \mathrm{~kb}$ & $1.8 \mathrm{~kb}$ & $9.0 \mathrm{~kb}$ & $7.5 \mathrm{~kb}$ \\
\hline \multicolumn{5}{|c|}{ Antidepressant treatments } \\
\hline Tranylcypromine & $203 \pm 19^{*}$ & $124 \pm 10$ & $91 \pm 7$ & $106 \pm 6$ \\
\hline Mianserin & $125 \pm 10$ & $106 \pm 6$ & $107 \pm 3$ & $114 \pm 5$ \\
\hline Sertraline & $84 \pm 8$ & $91 \pm 4$ & $98 \pm 6$ & $95 \pm 7$ \\
\hline Desipramine & $113 \pm 18$ & $120 \pm 18$ & $107 \pm 8$ & $105 \pm 4$ \\
\hline \multicolumn{5}{|c|}{ Nonantidepressants treatments } \\
\hline Morphine & $100 \pm 6$ & $118 \pm 16$ & $104 \pm 10$ & $111 \pm 12$ \\
\hline Cocaine & $95 \pm 14$ & $89 \pm 6$ & $106 \pm 8$ & $105 \pm 8$ \\
\hline Haloperidol & $74 \pm 16$ & $80 \pm 8$ & $96 \pm 6$ & $99 \pm 7$ \\
\hline
\end{tabular}

The influence of chronic drug treatments on levels of BDNF and trkB mRNA in frontal cortex was determined 3 hr after the last treatment by Northern blot analysis as described in Materials and Methods. Levels of mRNA were quantified by densitometry and standardized for the amount of mRNA in each lane by reprobing the filters with radiolabeled cyclophilin. Data are presented as percentage of vehicle, mean $\pm \mathrm{SEM}$. Analysis of variance comparing the BDNF mRNA $(4.4 \mathrm{~kb})$ levels in vehicle or antidepressant treated groups revealed a significant difference $[F(4$, $42)=9.14, p<0.0001]$; post hoc analysis (Fisher's test) indicated that tranylcypromine treatment significantly influenced levels of BDNF mRNA relative to the vehicle group.
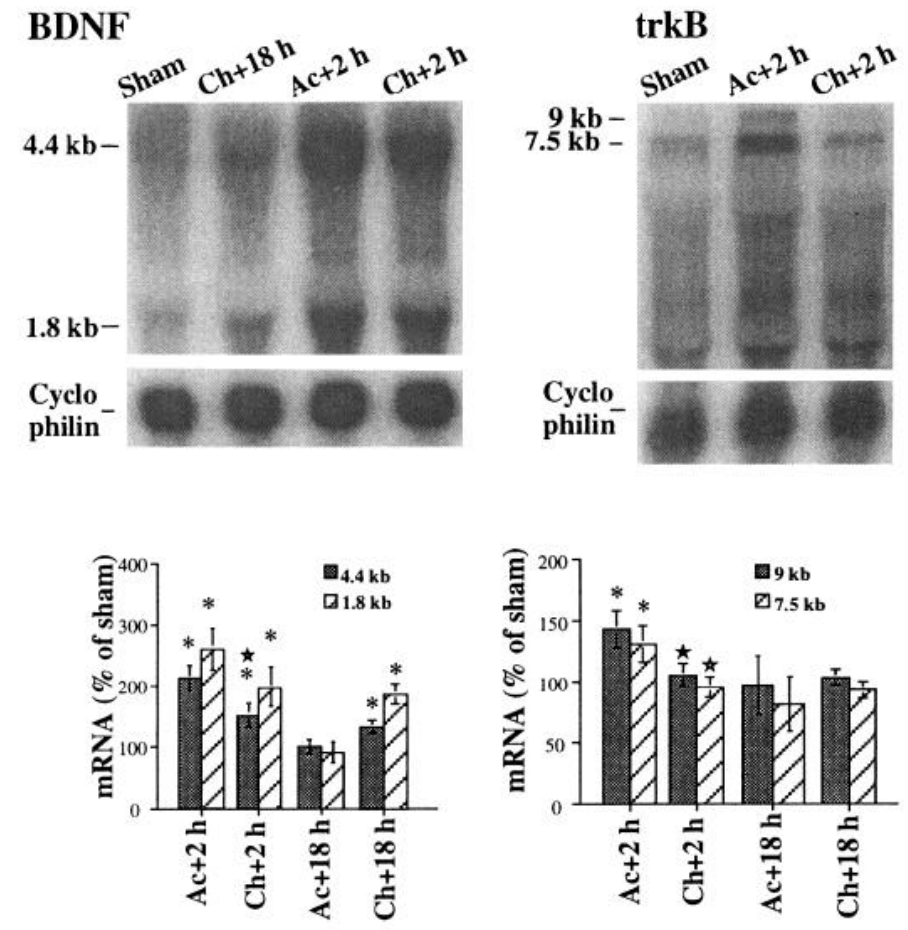

Figure 6. Regulation of BDNF and trkB mRNA in hippocampus by ECS treatment. The influence of acute and chronic ECS treatments on levels of BDNF and trkB mRNA in sections of hippocampus determined by Northern blot analysis. The level of mRNA in each band was quantified by densitometry and standardized for the amount of mRNA in each lane, which was determined by reprobing the filters with radiolabeled cyclophilin. The results are expressed as percent of sham $(100 \%)$ and are the mean \pm SEM. Analysis of variance comparing BDNF or trkB mRNA levels revealed the following differences: BDNF $4.4 \mathrm{~kb}$ band $[F(3,34)=12.10, p<0.0001] ;$ BDNF $1.8 \mathrm{~kb}$ band $[F(3,34)$ $=10.70, p<0.0001]$; trkB $9.0 \mathrm{~kb}$ band $[F(3,34)=5.95, p<0.01]$; and trkB $7.5 \mathrm{~kb}$ band $[F(3,34)=3.13, p<0.05]$. The indicated groups were found to be significantly different from the vehicle treated group (Fisher's test): *compared to sham; iscompared to acute $+2 \mathrm{hr}$.

\section{BDNF}
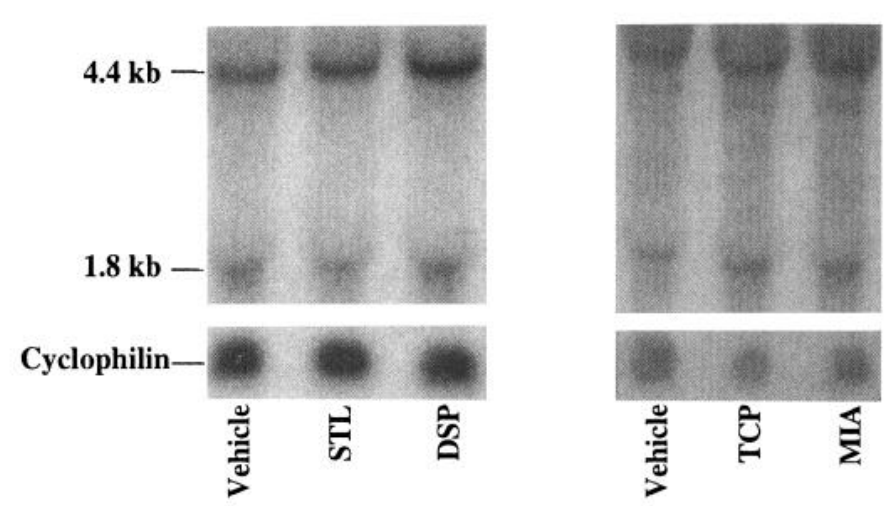

trkB

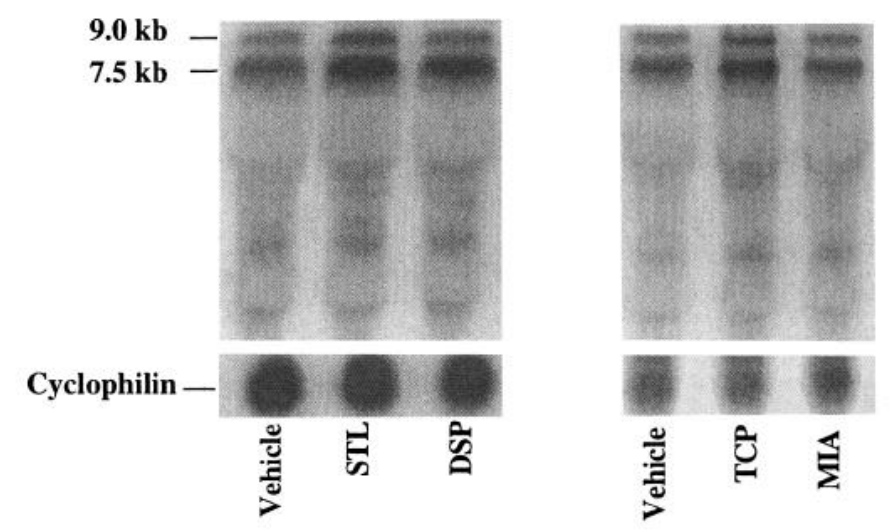

Figure 7. Chronic antidepressant drug treatments increase levels of BDNF and trkB mRNA in hippocampus. The influence of vehicle, sertraline $(S T L)$, desipramine $(D S P)$, tranylcypromine $(T C P)$, or mianserin (MIA) treatments (once daily for $21 \mathrm{~d}$ ) on levels of BDNF and trkB mRNA were determined $3 \mathrm{hr}$ after the last treatment by Northern blot analysis. Representative autoradiograms for each treatment condition are shown. The level of mRNA in each sample was standardized by reprobing the filters with radiolabeled cyclophilin. 
Table 2. Regulation of BDNF and trkB mRNA in hippocampus by chronic ECS and antidepressant drug treatments

\begin{tabular}{|c|c|c|c|c|}
\hline \multirow[b]{2}{*}{ Treatment } & \multicolumn{2}{|c|}{ BDNF mRNA } & \multicolumn{2}{|l|}{ trkB mRNA } \\
\hline & $4.4 \mathrm{~kb}$ & $1.8 \mathrm{~kb}$ & $9.0 \mathrm{~kb}$ & $7.5 \mathrm{~kb}$ \\
\hline \multicolumn{5}{|c|}{ Chronic antidepressant treatments } \\
\hline Tranylcypromine & $181 \pm 28 *$ & $158 \pm 29^{*}$ & $139 \pm 9^{*}$ & $142 \pm 7^{*}$ \\
\hline Mianserin & $144 \pm 18 *$ & $147 \pm 18^{*}$ & $91 \pm 14$ & $85 \pm 11$ \\
\hline Sertraline & $120 \pm 6^{*}$ & $104 \pm 11$ & $136 \pm 12^{*}$ & $135 \pm 11^{*}$ \\
\hline Desipramine & $126 \pm 8^{*}$ & $109 \pm 20$ & $141 \pm 14^{*}$ & $134 \pm 13^{*}$ \\
\hline \multicolumn{5}{|c|}{ Acute antidepressant treatments } \\
\hline Tranylcypromine & $112 \pm 14$ & $102 \pm 15$ & $91 \pm 13$ & $93 \pm 17$ \\
\hline Mianserin & $104 \pm 7$ & $101 \pm 7$ & $119 \pm 17$ & $116 \pm 16$ \\
\hline Sertraline & $93 \pm 6$ & $75 \pm 6$ & $98 \pm 6$ & $100 \pm 9$ \\
\hline Desipramine & $112 \pm 13$ & $110 \pm 14$ & $94 \pm 12$ & $92 \pm 13$ \\
\hline \multicolumn{5}{|c|}{ Chronic nonantidepressants treatments } \\
\hline Morphine & $102 \pm 22$ & $76 \pm 17$ & $96 \pm 5$ & $92 \pm 4$ \\
\hline Cocaine & $95 \pm 4$ & $97 \pm 9$ & $100 \pm 11$ & $86 \pm 7$ \\
\hline Haloperidol & $106 \pm 8$ & $76 \pm 7^{*}$ & $102 \pm 9$ & $87 \pm 8$ \\
\hline
\end{tabular}

Levels of BDNF and trkB mRNA in hippocampus were determined $3 \mathrm{hr}$ after the last chronic or acute drug treatments by Northern blot as described in Materials and Methods. Levels of mRNA were quantified by densitometry and standardized for the amount of mRNA in cach lanc, determined by reprobing the filters with radiolabeled cyclophilin. Data are presented as percentage of vehicle, mean \pm SEM. Analysis of variance comparing levels of BDNF and trkB mRNA in vehicle and chronic antidepressant treated groups revealed a significant difference: BDNF $4.4 \mathrm{~kb}$ band $[F(4,12)=7.11, p<0.001]$ : BDNF $1.8 \mathrm{~kb}$ band $[F(4,42)=2.64, p<0.05]$; trkB $9.0 \mathrm{~kb}$ band $[F(4,40)=$ $6.13, p<0.001]$; and trkB $7.5 \mathrm{~kb}$ band $[F(4,40)=9.04, p<0.0001]$; the indicated groups (*) were found to be significantly different from the vehicle treated group by Fisher's post hoc test. No significant differences were found by analysis of variance in the acute antidepressant treatment groups. A significant difference in levels of BDNF (1.8 $\mathrm{kb})$ mRNA was observed in the nonantidepressant treatment groups $[F(2,15)=3.41, p<0.05]$; post hoc analysis (Fisher's test) revealed that chronic haloperidol significantly influenced levels of BDNF mRNA relative to the vehicle treatment group.

en to determine if antidepressant treatments influence this downregulation of BDNF mRNA by stress. Acute restraint stress (45 min) decreased levels of BDNF mRNA in the hippocampus by $-50 \%$ (Fig. 8), confirming the report of Smith et al. (1995). In a preliminary study, a single dose of tranylcypromine, administered $2 \mathrm{hr}$ after restraint stress, did not significantly block the downregulation of BDNF mRNA (not shown). This is not surprising, given that the actions of antidepressant treatments are dependent on chronic administration. In a second series of experiments antidepressants were administered chronically (21 d) prior to restraint stress. In this case, chronic antidepressant pretreatment completely blocked the downregulation of BDNF mKNA resulting from acute restraint stress (Fig. 8).

\section{Discussion}

Chronic ECS increased the induction and prolonged the duration of $\mathrm{BDNF}$ and trkB mRNA, but the regulation differed in the brain regions examined. Chronic ECS increased acute seizure induction of BDNF and trkB mRNA in all regions examined, with the exception of the dentate gyrus granule cell layer, where the induction was dccreased, although there was still a highly significant level of induction ( 16-fold). Chronic ECS also prolonged the duration of expression for BDNF and trkB mRNA in most brain regions, with the exception of frontal cortex: this effect was most prominent in the dentate gyrus granule cell layer, where levels of BDNF remained elevated $\sim$ two- to threefold for up to $18 \mathrm{hr}$ after the last treatment. There were also two notable long-term effects after a single ECS: levels of BDNF mRNA were significantly decreased in the CA3 pyramidal cell layer and increased in layer 2 of piriform cortex $18 \mathrm{hr}$ after a single treatment.
There are several possible mechanisms by which chronic ECS could regulate the induction and prolong the expression of BDNF and trkB mRNA. Increased seizure induction of BDNF and trkB mRNA could result from increased efficacy of neurotransmission: repeated seizures increase the sensitivity to subsequent seizure stimuli and increase neuronal sprouting (see Lindvall et al., 1994), effects that could result in activation of a greater number of neurons that express BDNF and trkB mRNA. Alternatively, the intracellular pathways that mediate expression of BDNF and trkB mRNA may be enhanced. Expression of BDNF in cultured cells is induced by activation of the cyclic AMP system and voltage sensitive $\mathrm{Ca}^{2+}$ channels (Ghosh et al., 1994), and we have provided evidence that ECS-induction of BDNF mRNA in hippocampus is mediated by CREB, the cyclic AMP response element binding protein (Nibuya et al., 1994). We have also found that chronic ECS increases levels of cyclic AMP-dependent protein kinase and CREB (Nestler et al., 1989; Nibuya and Duman, unpublished observations), effects that could result in elevated expression of BDNF mRNA. Prolonged expression of BDNF mRNA may also result from continued activation of voltage-sensitive $\mathrm{Ca}^{2+}$ channels, as reported in cultured cells (Ghosh et al., 1994). Less is known about the intracellular pathways that govern the expression of trkB mRNA, but similar mechanisms could be involved. Another possibility is that regulation of mRNA stability contributes to the increased expression of BDNF and trkB mRNA. The mechanisms underlying the decreased induction of BDNF and trkB mRNA in the dentate gyrus granule cell layer after chronic ECS treatment may involve differential regulation of alternate signal transduction pathways and/or transcriptional repressors in these cells.

The expression of BDNF and trkB mRNA in hippocampus 


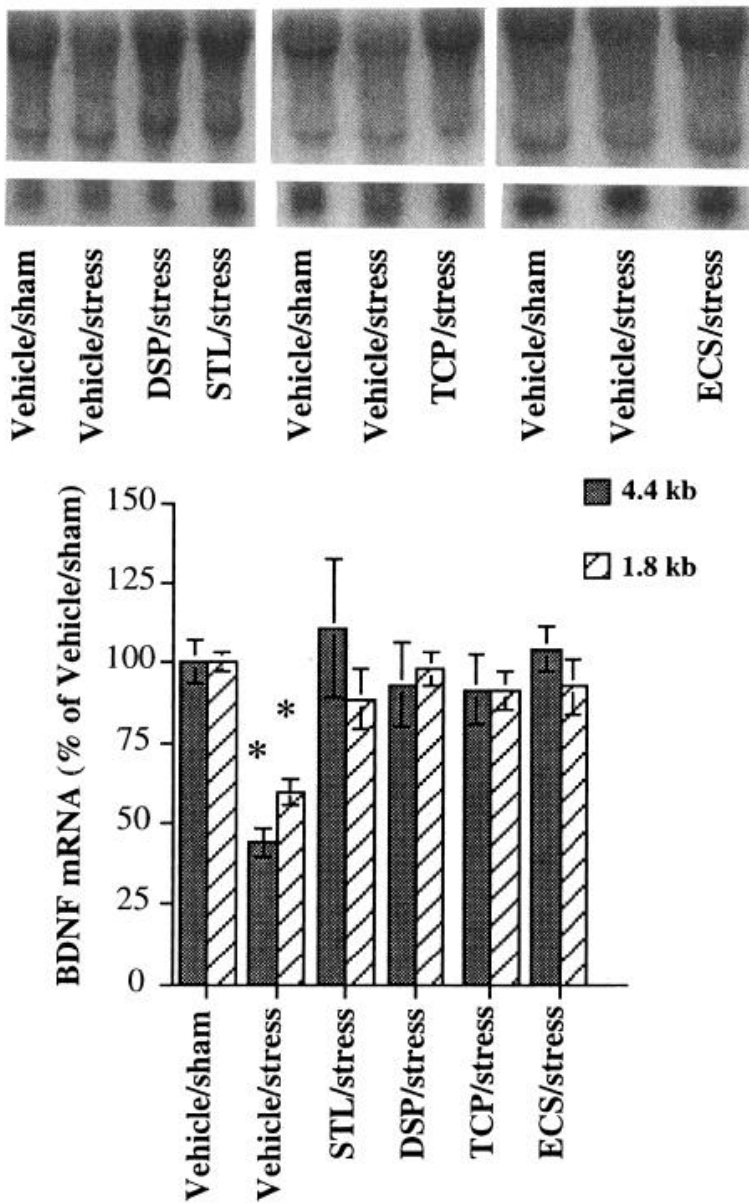

Figure 8. Chronic antidepressant treatments block the downregulation of BDNF in hippocampus by acute restraint stress. Rats were administered vehicle, sertraline (STL), desipramine (DSP), or tranylcypromine $(T C P)$ for $21 \mathrm{~d}$, ECS for $10 \mathrm{~d}$, or received vehicle/sham treatments for the corresponding times. Eighteen hours after the last treatment rats were subjected to restraint stress for $45 \mathrm{~min}$, sacrificed immediately, and levels of BDNF mRNA in hippocampus were determined by Northern blot. Representative autoradiograms resulting from Northern blots are shown. The level of mRNA in each band was quantified by densitometry and standardized for the amount of mRNA in each lane by reprobing the filters with radiolabeled cyclophilin. Analysis of variance comparing BDNF mRNA levels in the vehicle, stress, and drug treatment groups revealed a significant difference: BDNF $4.4 \mathrm{~kb}$ band $[F(4,22)=5.19, p<0.01]$ and BDNF $1.8 \mathrm{~kb}$ band $[F(4,22)=8.84$, $p<0.001]$. Analysis of variance comparing levels of BDNF mRNA in the sham, stress, and ECS groups revealed a significant difference: BDNF $4.4 \mathrm{~kb}$ band: $[F(2,6)=52.23, p<0.001]$ and BDNF $1.8 \mathrm{~kb}$ band $[F(2,6)=13.30, p<0.01]$. The vehicle/stress group $(*)$ was found to be significantly different from the vehicle/sham, as well as the STL/stress, DSP/stress, or TCP/stress pretreated groups (Fisher's test).

was also increased by chronic antidepressant drug treatments. Most of these drugs increase levels of norepinephrine and/or serotonin, via blockade of monoamine reuptake or metabolism, but these acute actions were not sufficient to increase levels of BDNF and trkB mRNA. The ability of chronic antidepressant drugs to increase BDNF and trkB mRNA may result from adaptations of intracellular pathways. We have found that chronic antidepressant drug treatments, like chronic ECS, increase nuclear levels of cyclic AMP-dependent protein kinase and CREB (Nestler et al., 1989; Nibuya and Duman, unpublished observations). Upregulation of the cyclic AMP-PKA-CREB cascade by chronic antidepressant drug treatments could underlie the increased expression of BDNF and trkB mRNA.

Increased expression of $\mathrm{BDNF}$ and trkB in response to chronic ECS and antidepressant drugs could have beneficial effects on neuronal function and survival. This possibility is supported by the report that prior exposure to seizure has a neuroprotective effect against subsequent exposure to kainic acid (Kelly and MacIntyre, 1994). Although the mechanisms underlying this neuroprotection have not been identified, it is possible that induction of BDNF is a contributing factor. BDNF has been shown to increase the survival and growth of neurons in culture and in vivo (see Lindsay et al., 1994; Lindvall et al., 1994): in primary cultures of cortical neurons, activation of voltage-sensitive $\mathrm{Ca}^{2+}$ channels results in prolonged expression of BDNF and increased survival of cultured neurons (Ghosh et al., 1994). The prolonged expression of BDNF after chronic ECS or antidepressant drug treatments may have a similar effect on the survival and growth of neurons in vivo. One effect of BDNF that could be relevant to the therapeutic actions of antidepressants is regulation of serotonin neurons; local infusion of BDNF into midbrain or cerebral cortex is reported to increase serotonin levels (Siuciak et al., 1994b) and to protect serotonin neurons from neurotoxininduced damage (Mamounas et al., 1994). BDNF could thereby enhance the functional capacity of serotonin neurons and allow them to respond to antidepressant treatments. BDNF may also influence norepinephrine neurons, although NT-3 is reported to have more potent effects on these monoamine neurons (Friedman et al., 1993; Arenas et al., 1994). Future studies will determine the influence of antidepressant treatments on expression of NT-3, as well as other neurotrophins.

Elevated expression of BDNF and increased neuronal survival could be of particular importance when the survival or function of neurons is compromised by stress or other neuronal insults. Repeated stress can result in neuronal atrophy and death of vulnerable neurons, and can increase the vulnerability to other neuronal insults, including excitotoxins, hypoxia-ischemia, and hypoglycemia (see McEwen and Gould, 1990; Stein-Behrens et al., 1994). In addition to increasing the expression of BDNF mRNA, the ability of antidepressant treatments to block the downregulation of BDNF mRNA by stress could also help reduce the damaging effects of stress. In support of this hypothesis, chronic administration of an atypical antidepressant, tianeptine, is reported to block the atrophy of hippocampal neurons resulting from stress (Watanabe et al., 1992). Future studies will determine if chronic antidepressant treatments have similar neuroprotective effects against stress, as well as other neuronal insults. In addition, elevated expression of BDNF could play a role in the reinstatement of hippocampal feedback inhibition of the hypothalamic-pituitary-adrenal axis in response to antidepressant treatments: hypercortisolism in depression is thought to result, at least in part, from loss of hippocampal inhibition (Young et al., 1991).

The results of this study indicate that increased expression of BDNF and trkB mRNA may be a common target of antidepressant treatments. This is supported by the finding that five different classes of antidepressant treatments increase BDNF mRNA, and all but one atypical antidepressant drug increase trkB mRNA. These findings raise the possibility that increased expression of BDNF and trkB is involved in the therapeutic action of antidepressant treatments. This possibility is supported by behavioral studies demonstrating that direct administration of BDNF into the midbrain has antidepressant effects in animal 
models of depression. Increased expression of BDNF may be of particular relevance when depression is related to prior exposure to stressful stimuli or other types of neuronal insult. In these cases, increased expression of BDNF and trkB could protect neurons from further damage or ameliorate neurons already damaged by stress. Neuronal injury resulting from exposure to prior insult, or a genetic vulnerability, could cxplain why stress only leads to depression in certain individuals. Future studies will be required to confirm that BDNF is a common target of antidepressant treatments and to examine the role of neurotrophins in the treatment and pathophysiology of depression.

\section{References}

Arenas E, Persson H (1994) Neurotrophin-3 prevents the death of adult central noradrenergic neurons in vivo. Nature 367:368-371.

Baxter LR, Schwartz JM, Phelps ME, Mazziota JC, Guze BH, Selin CE, Gerner RH, Sumida RM (1989) Reduction of prefrontal cortex glucose metabolism common to three types of depression. Arch Gen Psychiatry 46:243.

Drevets WC, Videen TO, Price JL, Preskorn SH, Carmichael ST, Raichle ME (1992) A functional anatomical study of unipolar depression. J Neurosci 12:3628-3641.

Duman RS, Heninger GR, Nestler EJ (1994) Adaptations of receptorcoupled signal transduction pathways underlying stress- and druginduced neural plasticity. J Nerv Ment Dis 182:692-700.

Ernfors P, Bengzon J, Kokaia Z, Persson H, Lindvall O (1991) Increased levels of messenger RNAs for neurotrophic factors in the brain during kindling epileptogenesis. Neuron 7:165-176.

Friedman WJ, Ibanez CF, Hallbook F, Persson H, Cain LD, Dreyfus CF, Black IB (1993) Differential actions of neurotrophins in the locus coeruleus and basal forebrain. Exp Neurol 119:72-78.

Ghosh A, Carnahan J, Greenberg ME (1994) Requirement for BDNF in activity-dependent survival of cortical neurons. Science 263:16181623.

Hayward MD, Duman RS, Nestler EJ (1990) Induction of the c-fos proto-oncogene during opiate withdrawal in the locus coeruleus and other regions of the rat brain. Brain Res 525:256-266.

Heninger GR, Charney DS (1987) Mechanisms of action of antidepressant treatments: implications for the etiology and treatment of depressive disorders. In: Psychopharmacology: the third generation of progress (Meltzer HY, ed), pp 535-544. New York: Raven.

Herman JP, Schafer MKH, Young EA, Thompson R, Douglass J, Akil H, Watson SJ (1989) Evidence for hippocampal regulation of neuroendocrine neurons of the hypothalamic-pituitary-adrenocortical axis. J Neurosci 9:3072-3082.

Hosoda K, Duman RS (1993) Regulation of $\boldsymbol{\beta}_{1}$-adrenergic receptor mRNA and ligand binding by antidepressant treatments and norepinephrine depletion in rat frontal cortex. J Neurochem 60:1335-1343.

Hudson CJ, Young LT, Li PP, Warsh JJ (1993) CNS signal transduction in the pathophysiology and pharmacotherapy of affective disorders and schizophrenia. Synapse 13:278-293.

Isackson PJ, Huntsman MM, Murray KD, Gall CM (1991) BDNF mRNA expression is increased in adult rat forebrain after limbic seizures: temporal patterns of induction distinct from NGF. Neuron 6:937-948

Jacobson L, Sapolsky R (1991) The role of the hippocampus in feedhack regulation of the hypothalamic-pituitary-adrenocortical axis. Endocr Rev 12:18-134.

Kelly ME, McIntyre DC (1994) Hippocampal kindling protects several structures from the neuronal damage resulting from kainic acid-induced status epilepticus. Brain Res 634:245-256.

Lindsay RM, Wiegand SJ, Anthony Altar CA, DiStefano PS (1994) Neurotrophic factors: from molecule to man. Trends Neurosci 17: $182-190$.

Lindvall O, Kokaia Z, Bengzon J, Elmer E, Kokaia M (1994) Neurotrophins and brain insults. Trends Neurosci 17:490-496.

Mamounas LA, Blue ME, Siuciak JA, Anthony Altar C (1994) BDNF prevents the neurotoxin-induced loss of 5-HT axons and promotes sprouting of uninjured 5-HT axons in rat brain. Soc Neurosci Abstr 20:441.

McEwen BS, Gould E (1990) Adrenal steroid influences on the survival of hippocampal neurons. Biochem Pharmacol 40:2393-2402.

Middlemas DS, Lindberg RA, Hunter T (1991) trkB, a neural receptor protein tyrosine kinase: evidence for a full length and two truncated receptors. Mol Cell Biol 11:143-153.

Morinobu S, Nibuya M, Duman RS (1995) Chronic antidepressant treatment down-regulates the induction of c-fos mRNA in response to acute stress in rat frontal cortex. Neuropsychopharmacology 12 : 221-228.

Nestler EJ, Terwilliger RZ, Duman RS (1989) Chronic antidepressant administration alters the subcellular distribution of cyclic AMP-dependent protein kinase in rat frontal cortex. J Neurochem 53:16441647.

Nibuya M, Rydelek Fitzgerald L, Russell DS, Nestler EJ, Duman RS (1994) Induction of BDNF and trkB by electroconvulsive seizure: regional regulation and role of CREB. Soc Neurosci Abstr 24:1312.

Sapolsky RM, Krey LC, McEwen BS (1985) Prolonged glucocorticoid exposure reduces hippocampal neuron number: implications for aging. J Neurosci 5:1222-1227.

Sapolsky RM, Uno H, Robert CS, Finsh CE (1990) Hippocampal damage associated with prolonged glucocorticoid exposure in primates. $\mathbf{J}$ Neurosci 10:2897-2902.

Siuciak JA, Lewis D, Wiegand SJ, Lindsay RM (1994a) Brain derived neurotrophic factor (BDNF) produces an anti-depressant like effect in two animal models of depression. Soc Neurosci Abstr 20:1106.

Siuciak JA, Anthony Altar CA, Wiegand SJ, Lindsay RM (1994b) Antinociceptive effect of brain-derived neurotrophic factor and neurotrophin-3. Brain Res 633:326-330.

Smith MA. Makino S, Kvetnansky R, Post RM (1995) Stress alters the express of brain-derived neurotrophic factor and neurotrophin-3 mRNAs in the hippocampus. J Neurosci 15:1768-1777.

Stein-Behrens B, Mattson MP, Chang I, Yeh M, Sapolsky R (1994) Stress exacerbates neuron loss and cytoskeletal pathology in the hippocampus. J Neurosci 14:5373-5380.

Sulser F (1989) New perspectives on the molecular pharmacology of affective disorders. Psychol Sci 238:231-239.

Timmusk T, Palm K, Metsis M, Reintam T, Paalme V, Saarma M, Persson $\mathrm{H}$ (1993) Multiple promoters direct tissue specific expression of the rat BDNF gene. Neuron 10:475-489.

Uno H, Tarara R, Else JG, Suleman MA, Sapolsky RM (1989) Hippocampal damage associated with prolonged and fatal stress in primates. J Neurosci 9:1705-1711

Wooley CS, Gould E, McEwen BS (1990) Exposure to excess glucocorticoids alters dendritic morphology of adult hippocampal pyramidal neurons. Brain Res 531:225-231.

Watanabe Y, Gould E, McEwen BS (1992) Stress induces atrophy of apical dendrites of hippocampal CA3 pyramidal neurons. Brain Res 588:341-345.

Watanabe Y, Gould E, Daniels DC, Cameron H, McEwen BS (1992) Tianeptine attenuates stress-induced morphological changes in the hippocampus. Eur J Pharmacol 222:157-162.

Young EA, Haskett RF, Murphy-Weinberg V, Watson S.J, Akil H (1991) Loss of glucocorticoid fast feedback in depression. Arch Gen Psychiatry $48: 693-699$ 